\title{
Diagnostic Performance of Diffusion-Weighted and Conventional MR Imaging in Staging of Rectal Cancer
}

\section{Rektal Kanserin Evrelemesinde Difüzyon Ağırlıklı ve Konvansiyonel MR Görüntülemenin Tanısal Performansı}

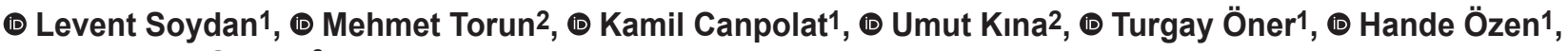 \\ (1) Ismail Ege Subaşı ${ }^{3}$ \\ 1 University of Health Sciences Turkey, Haydarpaşa Numune Training and Research Hospital, Clinic of Radiology, İstanbul, Turkey \\ 2University of Health Sciences Turkey, Haydarpaşa Numune Training and Research Hospital, Clinic of General Surgery, İstanbul, Turkey \\ ${ }^{3}$ Kartal Koşuyolu High Speciality Training and Research Hospital, Clinic of Gastroenterology, İstanbul, Turkey
}

\section{HIIIIII| ABSTRACT}

Aim: To determine the diagnostic accuracy of preoperative T2-weighted (T2W) and diffusion-weighted (DWI) magnetic resonance imaging (MRI) in tumor/node (T/N) staging of rectal cancer and impact of MRI in clinical decision-making.

Method: This retrospective study included 43 patients with rectal cancer who were admitted to our institution between January 2019 and December 2020. MRI was performed within 2 weeks before surgery. The diagnostic accuracy of MRI was assessed using the postoperative histopathologic results as a reference. Accuracy, sensitivity, specificity, positive predictive value, negative predictive value, and Kappa values were determined. The impact of preoperative MRI for appropriate treatment decision-making was also assessed.

Results: Overall, the diagnostic accuracy and Kappa value of T2W-MRI for T staging were $62.8 \%$ and 0.266 , respectively. The diagnostic accuracy and Kappa value of combined use of T2W and DWI for T staging were $65.1 \%$ and 0.251 and $41.9 \%$ and 0.011 for N staging, respectively. The diagnostic accuracy of MRI for treatment decision-making was $72.5 \%$ and $74.5 \%$ for $\mathrm{T} 2 \mathrm{~W}$ and $\mathrm{T} 2 \mathrm{~W}+\mathrm{DWI}$, respectively.

Conclusion: In rectal cancer, T2W-MRI enables a highly accurate preoperative assessment for the T stage but has moderate accuracy for the N stage. Keywords: Diffusion, MR, rectal cancer

\section{|||||||||| ÖZ}

Amaç: Rektal kanserin tümör/node (T/N) evrelemesinde preoperatif T2 ağırlıklı (T2W) ve difüzyon ağırlıklı (DWI) manyetik rezonans görüntülemenin (MRG) tanısal doğruluğunu ve MRG'nin klinik karar verme üzerindeki etkisini belirlemek.

Yöntem: Bu retrospektif çalışmaya Ocak 2019-Aralık 2020 tarihleri arasında kurumumuza başvuran 43 rektal kanserli hasta dahil edildi. MRG ameliyattan 2 hafta önce yapıldı. MRG'nin tanısal doğruluğu, postoperatif histopatolojik sonuçlar referans alınarak değerlendirildi. Doğruluk, duyarlılık, özgüllük, pozitif öngörü değeri, negatif öngörü değeri ve Kappa değerleri belirlendi. Preoperatif MRG'nin uygun tedavi yaklaşımını seçmedeki etkisi de değerlendirildi.

Bulgular: T evrelemesi için T2W-MRG'nin genel tanısal doğruluğu ve Kappa değeri sırasıyla \%62,8 ve 0,266 idi. T evrelemesi için T2W ve DWI'nın kombine kullanımının tanısal doğruluğu ve Kappa değeri sırasıyla \%65,1 ve 0,251 ve N evreleme için \%41,9 ve 0,011 idi. Tedaviye karar vermede MRG'nin tanısal doğruluğu T2W ve T2W/DWI için sırasıyla \%72,5 ve \%74,5 idi.

Sonuç: T2W MRG, rektal kanserin ameliyat öncesi değerlendirmesinde T evresi için iyi, N evresi için ise orta derece tanısal doğruluk sağlamaktadır. DWI'nın T2W görüntülemeye eklenmesi tanısal doğruluğu artırmamaktadır. Tedaviye karar vermede MRG'nin evreleme doğruluğu umut vericidir. Anahtar Kelimeler: Difüzyon, MR, rektal kanser 


\section{Introduction}

Colorectal cancer ranks third in terms of incidence but second in terms of mortality worldwide. ${ }^{1}$ Patient with rectal cancer undergoes imaging examinations to assess the disease extent and decide on optimal treatment method. The tumor/ node/metastasis (TNM) system adopted by the American Joint Committee on Cancer (AJCC) is used to stage the tumor extent. ${ }^{2} \mathrm{~T}$ staging in rectal cancer has a greater impact on the prognostic outcome than $\mathrm{N}$ staging. Several studies reported that patients with stage IIIA tumors as defined by the latest AJCC edition as a T1/T2 N + M0 tumor have a more favorable prognosis compared to patients with Stage IIA (T3/T4NOM0). ${ }^{3,4}$ Accurate clinical staging is also important for clinicians to select the appropriate treatment strategy, including surgery alone for patients with lowrisk tumors (pT2, N0, and no risk factors) or neoadjuvant chemoradiotherapy (CRT) followed by surgery for those with locally advanced rectal cancer (i.e., $\geq \mathrm{T} 3$ and/or $\mathrm{N}+$ stage and/or other risk factors). ${ }^{5}$

Endorectal ultrasonography, computed tomography, and magnetic resonance imaging (MRI) are used to evaluate the $\mathrm{T}$ stage of the primary tumor and the $\mathrm{N}$ stage of the surrounding lymph nodes prior treatment. ${ }^{6}$ Among these, high-resolution MRI is a widely used modality to detect and stage rectal cancer with high accuracy. ${ }^{7}$ The addition of diffusion-weighted (DWI) MR increased the diagnostic accuracy in detecting early tumors; however, its incremental role in increasing the $\mathrm{TN}$ stage accuracy remained controversial. Clinical misinterpretation of TN stages may result in overtreatment or undertreatment based on the current National Comprehensive Cancer Network (NCCN) guidelines (available at: https://www.nccn.org/professionals/ physician_gls/pdf/rectal.pdf).

This study aimed to evaluate the accuracy of MRI and the added diagnostic value of DWI for preoperative TN staging in patients with rectal cancer with the postoperative histopathological staging taken as a reference.

\section{Materials and Methods}

\section{Patients}

This retrospective study population consisted of patients with nonmetastatic rectal cancer who underwent surgery at Haydarpaşa Numune Training and Research Hospital between January 2019 and December 2020. The inclusion criteria were as follows: (1) confirmed pathological diagnosis of rectal cancer by endoscopy-guided biopsy before surgery; (2) tumor located between the rectosigmoid junctions, $2 \mathrm{~cm}$ proximal from the anal verge; (3) preoperative MRI within 2 weeks before surgery; and (4) postoperative pathological TN staging. Exclusion criteria are as follows: (1) recurrent rectal tumor; (2) neoadjuvant treatment before surgery; (2) tumor extending into the sigmoid colon beyond the rectosigmoid junction; and (3) patients without preoperative MRI.

The present study was performed in accordance with the ethical standards of the World Medical Association Declaration of Helsinki, and the study was approved by the Ethics Committee of our Institution. Informed consent was waived due to the retrospective nature of the study. Patient characteristics are shown in Table 1.

\section{MR Examination}

MRI was performed using a 1.5 T GE Optima $460 \mathrm{w}$ (GE Healthcare, Milwaukee, USA) with a phased-array multi-coil. Patients were scanned in a supine position with their feet entering the MR gantry. Following the scout scan, sagittal T2-weighted turbo spin-echo (T2W-TSE) images were obtained. These sagittal images were used to plan the highresolution axial T2W-TSE scans, which were perpendicular to the long axis of the tumor. For DWI, echo planar imaging sequences were used with $b$ values of 0,400 , and $800 \mathrm{~s} / \mathrm{mm}^{2}$. Parameters of the scan protocol were as follows: Repetition Time (TR), 3500 ms; Echo Time (TE), 80 ms; Field of View (FOV), 28x32 cm; Matrix, 276x384; Slice Thickness, 5 mm; and Gap, $1 \mathrm{~mm}$. For DWI, TR: 2,500 ms, TE: $65 \mathrm{~ms}$, Slice Thickness: $6.0 \mathrm{~mm}$, Gap: $1.0 \mathrm{~mm}$, FOV: $35 \times 35 \mathrm{~cm}$, and Matrix: 192x192.

An additional oblique coronal scan along the long axis of the anal canal was also acquired, which is important especially for low rectal tumor evaluation. The scan time was approximately $30 \mathrm{~min}$.

\section{Interpretation of MR Images}

Images were interpreted by two radiologists with 4 and 15 years of experience in gastrointestinal radiology, respectively. The radiologists knew the history of all patients but were unaware of their histopathological results. For image analysis, they first located the tumor using only the T2WI on the sagittal and axial planes. Then they staged the tumor using the axial $\mathrm{T} 2 \mathrm{~W}$ and restaged it using the combination of T2W and DWI. The final decision on staging was reached by consensus for each case.

\section{TN Stage Assessment Criteria}

The criteria used to determine the $\mathrm{T}$ stage were based on the AJCC seventh TNM classification. ${ }^{3}$ Staging was done on T2W axial images. T1 tumor was defined as a tumor contained within the hyperintense submucosal level of the rectal wall without hypointense muscle layer disruption. T2 tumor was defined as a loss of interface between the submucosa and muscle layer and a discontinuous muscularis propria. However, the integrity of the outermost hypointense muscular layer remains undisrupted. T3 tumor was defined 
as an infiltration of the adjacent mesorectal fat tissue. T4 tumor was defined as a tumor invasion of nearby organs or pelvic wall with loss of fat planes in between (Figure 1). Pelvic and mesorectal lymph nodes were identified on axial $\mathrm{T} 2 \mathrm{~W}$ and verified as structures with an increased DWI signal. The presence of nodal metastasis was considered in the mesorectal or pelvic nodes with a short axis of $>8 \mathrm{~mm}$.

\section{Postoperative Histopathological Examination}

Surgery with mesorectal excision was performed in all patients. Following the postoperative formalin fixation for $24 \mathrm{~h}$, the resected specimens were transversely sliced at 5-mm intervals. Slices were embedded in paraffin, sectioned, and examined histologically after hematoxylin and eosin staining. The size and location of the tumor were noted and the depth of tumor invasion was evaluated based on the TNM classification. ${ }^{3}$ The pathologist was unaware of the MRI findings.

\section{Statistical Analysis}

The diagnostic accuracy, sensitivity, specificity, positive predictive value (PPV), and negative predictive value (NPV) were calculated for each T stage and NO vs. N+. As the number in each subset of $\mathrm{T}$ stages was small, patients were combined as $\mathrm{T} 1+\mathrm{T} 2$ and $\mathrm{T} 3+\mathrm{T} 4$, and the respective diagnostic performances were calculated as such. Receiver operator characteristics curve analyses were performed and the area under the curve (AUC) was calculated. A $p<0.05$ indicated a statistically significant difference. Consistencies between T2W-MRI and T2W+DWI and pathological staging were tested using the Kappa coefficients. A weighted Kappa value of $<0.20$ indicated poor agreement, $0.21-0.40$ indicated fair agreement, 0.41-0.60 indicated moderate agreement, 0.61-0.80 indicated substantial agreement, and 0.81-1.0 indicated almost perfect agreement. Statistical analyses were performed using the Statistical Package for the Social Sciences version 19.0 (SPSS Inc., IBM Corp., Armonk, NY, USA).

\section{Results}

\section{Patient Demographics and Clinical Data}

A total of 43 patients ( 27 male and 16 female) with a mean age of $59.23 \pm 9.16$ years, range $38-76$ years were included in the final analysis (Table 1).

\section{T Staging of Rectal Cancer by T2W and T2W + DWI}

After histopathologic examination, 7 (16.3\%) patients were staged as pT1, $8(18.6 \%)$ as pT2, $23(53.5 \%)$ as pT3, and 5 $(11.6 \%)$ as pT4. The accuracy by T2W and T2W+DWI of each T stage was $83.7 \%$ and $86.1 \%$ for $\mathrm{T} 1,67.4 \%$ and $75 \%$ for T2, $60.5 \%$ and $53.5 \%$ for T3, and $81.4 \%$ and $86.1 \%$ for $\mathrm{T} 4$, respectively. The sensitivity of each $\mathrm{T}$ stage was $0 \%$ and $14.3 \%$ for $\mathrm{T} 1,75.0 \%$ and $60 \%$ for $\mathrm{T} 2,52.2 \%$ and 43.5 for $\mathrm{T} 3$, and $40.0 \%$ and $40 \%$ for T4, respectively. The specificity of each T stage was $100 \%$ and $100 \%$ for T1, $65.7 \%$ and $30 \%$ for $\mathrm{T} 2,70.0 \%$ and $65 \%$ for $\mathrm{T} 3$, and $86.8 \%$ and 92.1 for $\mathrm{T} 4$, respectively. The PPV of each T stage was $0 \%$ and $85.7 \%$ for $\mathrm{T} 1,33.3 \%$ and $91.3 \%$ for $\mathrm{T} 2,66.7 \%$ and $58.9 \%$ for T3, and $28.6 \%$ and $40 \%$ for T4, respectively. The NPV for each T stage was $83.7 \%$ and $86.1 \%$ for $\mathrm{T} 1,92.0 \%$ and $62.8 \%$ for $\mathrm{T} 2,56.0 \%$ and $50 \%$ for T3, and $91.7 \%$ and $92.1 \%$ for T4, respectively (Table 2 ). The Kappa value for $\mathrm{T}$ staging was 0.213 .

After combining $\mathrm{T} 1$ and $\mathrm{T} 2$ as $\mathrm{T} 1-2$ and combining $\mathrm{T} 3$ and $\mathrm{T} 4$ as T3-4, the staging of patients by $\mathrm{T} 2 \mathrm{~W}$ and $\mathrm{T} 2 \mathrm{~W}+\mathrm{DWI}$ were as follows: 15 (34.9\%) were staged as pT1-2 and 28 (65.1\%) as pT3-4 (Table 2).

The AUC of $\mathrm{T}$ staging with conventional MR was 0.630 $(\mathrm{p}=0.165 ; \mathrm{p}>0.05)$, whereas the AUC of $\mathrm{T}$ staging with conventional MR with DWI was $0.680(\mathrm{p}=0.054 ; \mathrm{p}>0.05)$. The confidence level was $0.9 \%$.

\section{N Staging of Rectal Cancer}

$\mathrm{N}$ staging ( $\mathrm{N} 0$ vs. $\mathrm{N}+$ ) was determined using the $\mathrm{T} 2 \mathrm{~W}+\mathrm{DWI}$ with histopathological findings as reference. The Kappa value for $\mathrm{N}$ positivity was 0.011 (Table 3 ).
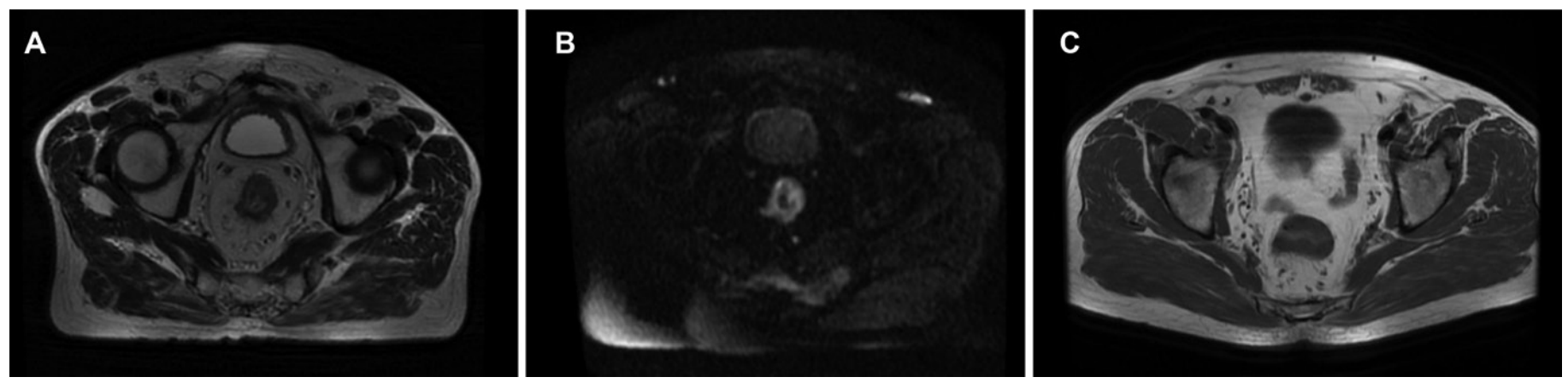

Figure 1. (A). T3 rectal tumor with specular extensions into the mesorectal fat tissue on T2W (B). DWI of T3 tumor with high signal on the tumorous rectal wall showing restricted diffusion (C). T2W of a T2 rectal cancer with maintained integrity of outer rectal wall but a loss of interface between mucosa and submucosa 
Table 1. Patient characteristics

\begin{tabular}{|c|c|c|}
\hline & & Mean \pm SD \\
\hline Age (years) total & & $59.23 \pm 9.16$ \\
\hline Men & & $59.19 \pm 7.98$ \\
\hline \multirow[t]{2}{*}{ Women } & & $59.29 \pm 10.99$ \\
\hline & & n (\%) \\
\hline \multirow{2}{*}{ Sex } & Men & $26(60.5 \%)$ \\
\hline & Women & $17(39.5 \%)$ \\
\hline \multirow{3}{*}{ Tumor location in rectum } & Low & $15(34.9 \%)$ \\
\hline & Middle & $19(44.2 \%)$ \\
\hline & Upper & $9(20.9 \%)$ \\
\hline \multirow{3}{*}{$\begin{array}{l}\text { Tumor histopathological differentiation } \\
\text { Grade }\end{array}$} & Well & $10(23.3 \%)$ \\
\hline & Moderate & $25(58.1 \%)$ \\
\hline & Poor & $8(18.6 \%)$ \\
\hline \multirow{3}{*}{ Tumor size $(\mathrm{cm})$ on pathology } & $\leq 3$ & $29(67.4 \%)$ \\
\hline & $4-5$ & $13(30.2 \%)$ \\
\hline & $\geq 6$ & $1(2.3 \%)$ \\
\hline \multirow{3}{*}{ Tumor histology } & Adenocarcinoma & $38(88.4 \%)$ \\
\hline & Mucinous adenocarcinoma & $4(9.3 \%)$ \\
\hline & Signet ring cell carcinoma & $1(2.3 \%)$ \\
\hline
\end{tabular}

SD: Standard deviation

Table 2. Comparison of MRI with histopathology in T staging

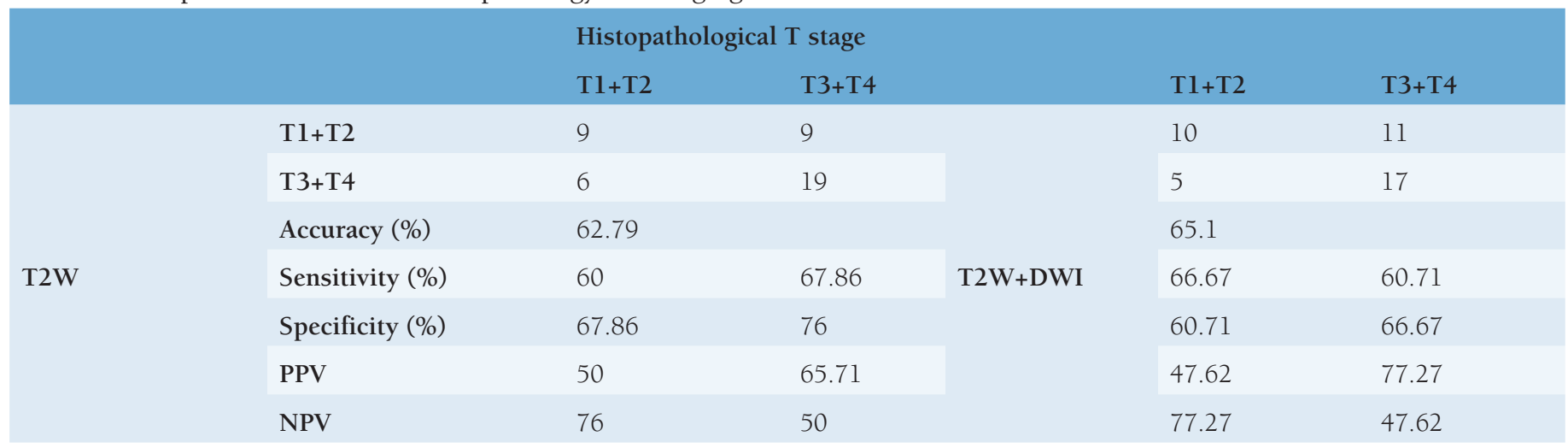

PPV: Positive predictive value, NPV: Negative predictive value, Kappa for T2W=0.266, P=0.078, p>0.05, Kappa for T2W/DWI=0.251, p=0.087, $\mathrm{p}>0.05$

\section{Effects of MR Staging on Treatment Strategy}

The accuracy rate of $\mathrm{T} 2 \mathrm{~W}$ and $\mathrm{T} 2 \mathrm{~W}+\mathrm{DWI}$ MRI for treatment decision-making was $72.5 \%$ and $74.5 \%$, respectively. The accuracy of these MR sequences to identify patients for upfront surgery was $63.3 \%$ and $65.2 \%$, respectively. The accuracy to identify patients for neoadjuvant therapy was $81.2 \%$ and $85.5 \%$ for respective sequences. The probability of understaging was $40 \%$ and overstaging was $27.10 \%$.

\section{Discussion}

The accurate $\mathrm{T}$ staging assessment in rectal cancer is important to identify patients who can benefit from perioperative neoadjuvant CRT and patients who can directly proceed to surgery. NCCN guidelines recommend neoadjuvant CRT for suspected or proven T3/T4 tumors (locally advanced rectal cancer) and/or regional node involvement. ${ }^{5}$ The decision for neoadjuvant therapy is 
Table 3. Comparison of MRI with histopathology in N staging

\begin{tabular}{lll} 
N staging with T2W+DWI & \multicolumn{2}{l}{ Histopathological N stage } \\
& Positive & Negative \\
Positive & 12 & 22 \\
Negative & 3 & 6 \\
Accuracy (\%) & 41.86 & 21.43 \\
Sensitivity (\%) & 80.00 & 80.00 \\
Specificity (\%) & 21.43 & 66.67 \\
PPV & 35.29 & 35.29 \\
NPV & 66.67 &
\end{tabular}

PPV: Positive predictive value, NPV: Negative predictive value, MRI: Magnetic resonance imaging

reached by multidisciplinary consensus at our hospital and is tailored on a patient basis. However, only T3 and T4 tumors without neoadjuvant treatment were included, either because the tumor extended above the peritoneal reflection or caused bowel obstruction rendering the case a medical emergency for urgent surgery since we aimed to investigate the diagnostic performance of MR in rectal cancer without intervening neoadjuvant effects. Preoperative CRT was reported to reduce the tumor burden, increase the rate of sphincter preservation, downstage the tumor by $50 \%-60 \%$, and result in a pathologic complete response in 10\%-30\% of patients. ${ }^{89}$ Tumor overstaging may lead to unnecessarily extensive surgery for $\mathrm{T} 1$ or $\mathrm{T} 2$ tumors with increased risk of morbidity and mortality, whereas understaging may result in disease spread that would be otherwise curatively resected with an appropriate surgical approach. Our study revealed a diagnostic accuracy of MR examination using T2W and T2W+DWI in T staging of $65.1 \%$ and $62.8 \%$, respectively.

The accuracy of conventional MRI for T staging of rectal cancer was reported in the literature to range between $67 \%$ and $100 \%{ }^{7,10,11,12,13,14,15,16,17}$ The sensitivity and specificity of MRI for tumor T staging also vary considerably, with the sensitivity ranging from $29 \%$ to $57 \%$ and specificity ranging from $50 \%$ to $83 \% .^{10,11,12,13}$ The main limiting diagnostic difficulty of MR appears to be in differentiating Tl from $\mathrm{T} 2$ tumors and in the misinterpretation of some T2 tumors with an excessive desmoplastic response as T3 tumors. ${ }^{14}$ High diagnostic accuracy of MR for T1 and T2 tumors in our study should not be generalized as the accuracy would likely decrease in a study conducted with larger numbers of participants with T1/T2 tumors. For T1N0 tumors, NCCN guidelines suggest an endorectal ultrasound as a useful alternative. $^{3}$

Brown et al. ${ }^{15}$ found a $100 \%$ accuracy in T staging of 28 primary rectal cancers using high-resolution MR images, whereas Poon et al. ${ }^{16}$ and Rao et al. ${ }^{17}$ reported an overall accuracy of $74 \%$ and $85.1 \%$ for $\mathrm{T}$ staging using similar techniques, respectively. Xu et al. ${ }^{18}$ studied 354 cases of middle and lower rectal cancer and found a $78.2 \%$ overall accuracy. Compared to other studies, a lower overall MR accuracy $(62.3 \%-65.1 \%)$ in $\mathrm{T}$ staging was found in our study.

The use of DWI which reflects the restricted microdiffusion process of water molecules in malignant tissues was studied in the rectal tumor staging as it increases the accuracy of staging. Lu found that the DWI+T2W sequences did not result in a statistically significant increase in diagnostic performance. ${ }^{19}$ Feng et al. ${ }^{20}$ compared the diagnostic accuracies of DWI and T2W in T staging and found similar accuracies of both sequences. Our study revealed no added value of DWI to the conventional T2W in the overall diagnostic accuracy. However, Li reported that additional DWI examination to conventional MR sequences increased the diagnosis accordance rate from $71.42 \%$ to $92.85 \% .^{21}$ They suggested that combined use of DWI and conventional sequences were especially useful for early $\mathrm{T}$ stages detection. ${ }^{21}$

Overall, MR tended to be less accurate for rectal cancer $\mathrm{N}$ staging than for $\mathrm{T}$ staging. The overall reported sensitivities and specificities of $\mathrm{T} 2 \mathrm{~W}$ for nodal staging ranged 55\%$78 \%^{18,22}$, and additional DWI was reported to result in an increase of $10 \%-83 \%$ in the overall number of detected lymph nodes compared to T2W-MRI. ${ }^{23}$ However, the addition of DWI to T2W did not increase the accuracy of nodal staging achieved by $\mathrm{T} 2 \mathrm{~W}$ alone. ${ }^{23}$ In our study, the overall MR accuracy for $\mathrm{N}$ positivity was $41.9 \%$ with a Kappa value of 0.323 , indicating a fair agreement with histopathologic results. The reported relatively low accuracy in nodal staging lies in the fact that micrometastases in nodes cannot be detected by any current imaging modality. Moreover, approximately 20\% of all resected perirectal lymph nodes, which can harbor metastatic foci were not identified on MRI due to their small size. NCCN guidelines recommend a preoperative CRT for patients with cT3NO to avoid undertreatment as MRI may underestimate nodal staging. ${ }^{3,24}$

In our study, the diagnostic accuracy rate of MRI for treatment decision-making was $72.5-74.5 \%$. The understaging rate was $40 \%$ and the overstaging rate was $27.10 \%$, which was comparable to the results from previous studies $(15-30 \%)^{17}$ Maas et al. ${ }^{25}$ found a mean overstaging rate of $43 \%$ at $1.5 \mathrm{~T}$. Such regrouping would be better correlated with prognostic outcomes.

\section{Study Limitations}

Some limitations were encountered in this study. First, this retrospective study included a limited number of patients 
from a single institution. Second, circumferential resection margin involvement was not assessed, which is taken into account for making a therapeutical decision, especially in Europe. Third, slices in the oblique transverse plane were thicker $(5 \mathrm{~mm})$ and the FOV size $(28 \times 32 \mathrm{~cm})$ was also larger than suggested in guidelines $(3 \mathrm{~mm}$ and $32 \times 22 \mathrm{~cm}$, respectively). This resulted in a lower spatial resolution and contributed to a lower diagnostic performance due to the retrospective nature of the study. Fourth, only the size criterion was taken into account when evaluating the metastatic involvement of lymph nodes, whereas morphologic changes like irregular borders were ignored. Finally, all patients with T3 in our study were combined with patients with T4. However, T3 patients have different prognostic subgroups depending on the extent of the extramural tumor invasion from the muscularis propria. Thus, our combined T3/T4 grouping has a heterogenous prognostic spectrum. This limitation can be overcome in a future study with a larger number of patients in each $\mathrm{T}$ stage, where patients with $\mathrm{T} 3$ are divided into T3ab and T3cd and the study population is regrouped into T1/T2/ T3ab and T3cd/T4. Such regrouping is better correlated with prognostic outcomes.

\section{Conclusion}

In conclusion, conventional MRI combined with DWI allows a highly accurate preoperative assessment of $\mathrm{T}$ stages and moderately accurate preoperative assessment of $\mathrm{N}$ stage for rectal cancer and can help identify patients who benefit from neoadjuvant therapy and those who can proceed directly to surgery.

\section{Ethics}

Ethics Committee Approval: The present study was performed in accordance with the ethical standards of the World Medical Association Declaration of Helsinki, and the study was approved by the Ethics Committee of our Institution.

Informed Consent: Informed consent was waived due to the retrospective nature of the study.

Peer-review: Internally and externally peer reviewed.

\section{Authorship Contributions}

Surgical and Medical Practices: L.S., M.T., Concept: L.S., İ.E.S., Design: LS., M.T., K.C., U.K., T.Ö., H.Ö., Data Collection or Processing: LS., K.C., U.K., T.Ö., H.Ö., I.E.S., Analysis or Interpretation: LS., M.T., K.C., U.K., T.Ö., H.Ö., Literature Search: L.S., T.Ö., H.Ö., İ.E.S., Writing: L.S., M.T., H.Ö.

Conflict of Interest: No conflict of interest was declared by the authors.
Financial Disclosure: The authors declared that this study received no financial support.

\section{References}

1. Sung H, Ferlay J, Siegel RL, Laversanne M, Soerjomataram I, Jemal A, Bray F. Global Cancer Statistics 2020: GLOBOCAN Estimates of Incidence and Mortality Worldwide for 36 Cancers in 185 Countries. CA Cancer J Clin 2021;71:209-249.

2. Amin MB, Greene FL, Edge SB, Compton CC, Gershenwald JE, Brookland RK, Meyer L, Gress DM, Byrd DR, Winchester DP. The Eighth Edition AJCC Cancer Staging Manual: Continuing to build a bridge from a populationbased to a more "personalized" approach to cancer staging. CA Cancer J Clin 2017;67:93-99.

3. NCCN Clinical Practice Guidelines in Oncology. Rectal Cancer. NCCN 2021 Available from: https://www.nccn.org/professionals/physician_gls/ pdf/rectal.pdf.

4. Mo S, Dai W, Xiang W, Huang B, Li Y, Feng Y, Li Q, Cai G. Survival contradiction between stage iia and stage iiia rectal cancer: a retrospective study. J Cancer 2018;9:1466-1475.

5. Benson AB, Venook AP, Al-Hawary MM, Cederquist L, Chen YJ, Ciombor KK, Cohen S, Cooper HS, Deming D, Engstrom PF, Grem JL, Grothey A, Hochster HS, Hoffe S, Hunt S, Kamel A, Kirilcuk N, Krishnamurthi S, Messersmith WA, Meyerhardt J, Mulcahy MF, Murphy JD, Nurkin S, Saltz L, Sharma S, Shibata D, Skibber JM, Sofocleous CT, Stoffel EM, StotskyHimelfarb E, Willett CG, Wuthrick E, Gregory KM, Gurski L, FreedmanCass DA. Rectal cancer, version 2.2018, NCCN clinical practice guidelines in oncology. J Natl Compr Canc Netw 2018;16:874-901.

6. Bipat S, Glas AS, Slors FJ, Zwinderman AH, Bossuyt PM, Stoker J. Rectal cancer: local staging and assessment of lymph node involvement with endoluminal US, CT, and MR imaging--a meta-analysis. Radiology 2004;232:773-783.

7. Al-Sukhni E, Milot L, Fruitman M, Beyene J, Victor JC, Schmocker S, Brown G, Mcleod R, Kennedy E. Diagnostic accuracy of MRI for assessment of $\mathrm{T}$ category, lymph node metastases, and circumferential resection margin involvement in patients with rectal cancer: a systematic review and metaanalysis. Ann Surg Oncol 2012;19:2212-2223.

8. Park IJ, You YN, Agarwal A, Skibber JM, Rodriguez-Bigas MA, Eng C, Feig BW, Das P, Krishnan S, Crane CH, Hu CY, Chang GJ. Neoadjuvant treatment response as an early response indicator for patients with rectal cancer. J Clin Oncol 2012;30:1770-1776.

9. Das P, Skibber JM, Rodriguez-Bigas MA, Feig BW, Chang GJ, Wolff RA, Eng C, Krishnan S, Janjan NA, Crane CH. Predictors of tumor response and downstaging in patients who receive preoperative chemoradiation for rectal cancer. Cancer 2007;109:1750-1755.

10. Videhult P, Smedh K, Lundin P, Kraaz W. Magnetic resonance imaging for preoperative staging of rectal cancer in clinical practice: high accuracy in predicting circumferential margin with clinical benefit. Colorectal Dis 2007;9:412-419.

11. Torkzad MR, Hansson KA, Lindholm J, Martling A, Blomqvist L. Significance of mesorectal volume in staging of rectal cancer with magnetic resonance imaging and the assessment of involvement of the mesorectal fascia. Eur Radiol 2007;17:1694-1699.

12. Suzuki C, Torkzad MR, Tanaka S, Palmer G, Lindholm J, Holm T, Blomqvist L. The importance of rectal cancer MRI protocols on interpretation accuracy. World J Surg Oncol 2008;6:89.

13. Rovera F, Dionigi G, Boni L, Cutaia S, Diurni M, Dionigi R. The role of EUS and MRI in rectal cancer staging. Surg Oncol 2007;16(Suppl 1):S51-52.

14. Taylor FG, Swift RI, Blomqvist L, Brown G. A systematic approach to the interpretation of preoperative staging MRI for rectal cancer. AJR Am J Roentgenol 2008;191:1827-1835. 
15. Brown G, Richards CJ, Newcombe RG, Dallimore NS, Radcliffe AG, Carey DP, Bourne MW, Williams GT. Rectal carcinoma: thin-section MR imaging for staging in 28 patients. Radiology 1999;211:215-222.

16. Poon FW, Mcdonald A, Anderson JH, Duthie F, Rodger C, Mccurrach G, Mckee RF, Horgan PG, Foulis AK, Chong D, Finlay IG. Accuracy of thin section magnetic resonance using phased-array pelvic coil in predicting the T-staging of rectal cancer. Eur J Radiol 2005;53:256-262.

17. Rao SX, Zeng MS, Xu JM, Qin XY, Chen CZ, Li RC, Hou YY. Assessment of $\mathrm{T}$ staging and mesorectal fascia status using high-resolution MRI in rectal cancer with rectal distention. World J Gastroenterol 2007;13:4141-4146.

18. Xu L, Zhang Z, Qin Q, Zhang C, Sun X. Assessment of $\mathrm{T}$ and $\mathrm{N}$ staging with MRI(3)T in lower and middle rectal cancer and impact on clinical strategy. J Int Med Res 2020;48:300060520928685. doi: $10.1177 / 0300060520928685$.

19. Lu ZH, Hu CH, Qian WX, Cao WH. Preoperative diffusion-weighted imaging value of rectal cancer: preoperative $\mathrm{T}$ staging and correlations with histological T stage. Clin Imaging 2016;40:563-568.

20. Feng Q, Yan YQ, Zhu J, Xu JR. T staging of rectal cancer: accuracy of diffusion-weighted imaging compared with T2-weighted imaging on 3.0 tesla MRI. J Dig Dis 2014;15:188-194.
21. Li F, Zhang W, Li J, Zhu X, Chen H, Wu Y, Wang J. The clinical application value of MR diffusion-weighted imaging in the diagnosis of rectal cancer: A retrospective study. Medicine (Baltimore) 2018;97:e13732. doi: 10.1097/ MD.0000000000013732

22. Lahaye MJ, Engelen SM, Nelemans PJ, Beets GL, Van De Velde CJ, Van Engelshoven JM, Beets-Tan RG. Imaging for predicting the risk factors--the circumferential resection margin and nodal disease--of local recurrence in rectal cancer: a meta-analysis. Semin Ultrasound CT MR 2005;26:259-268.

23. Mir N, Sohaib SA, Collins D, Koh DM. Fusion of high b-value diffusionweighted and T2-weighted MR images improves identification of lymph nodes in the pelvis. J Med Imaging Radiat Oncol 2010;54:358-364.

24. Guillem JG, Díaz-González JA, Minsky BD, Valentini V, Jeong SY, Rodriguez-Bigas MA, Coco C, Leon R, Hernandez-Lizoain JL, Aristu JJ, Riedel ER, Nitti D, Wong WD, Pucciarelli S. cT3NO rectal cancer: potential overtreatment with preoperative chemoradiotherapy is warranted. J Clin Oncol 2008;26:368-373.

25. Maas M, Lambregts DM, Lahaye MJ, Beets GL, Backes W, Vliegen RF, Osinga-De Jong M, Wildberger JE, Beets-Tan RG. T-staging of rectal cancer: accuracy of 3.0 Tesla MRI compared with 1.5 Tesla. Abdom Imaging 2012;37:475-481. 